\title{
Innovation of College Course Assessment Method Based on Outcomes- Based Education Philosophy—Self-Service Mode
}

\author{
Tingdan Zheng \\ School of Business, Beijing Institute of Technology, Zhuhai campus, Guangdong, 519087, China. \\ Zheng_td@126.com
}

Keywords: Outcomes-Based Education, Self-service mode, Innovation of assessment method.

\begin{abstract}
A new idea of assessment method called self-service assessment mode is proposed base on Outcomes-Based Education philosophy. It means that learning tasks should be translated into test modules and teachers set test options on the basis of these modules. Besides, students can select any item from the test menu and cumulative total score as their final score. The total score of the menu can be less than, greater than or equal to 100 points. If points of the items that a student selects are less than 100, the final score is recorded as the total number of points he or she acquired in the examinations. However, if he or she chooses more than 100 points, the final results need to be converted in accordance with the formula. It aims to encourage the students who learn well, as well as motivate underachieving students. In addition, students can evaluate their learning situation through items selection.
\end{abstract}

\section{Introduction}

Essentially, the OBE (outcomes-Based Education) philosophy centers around "expected learning outcomes- realization of expected learning outcomes- evaluation of learning outcomes". Learning outcomes of OBE stress knowledge and enhanced ability acquired by students after learning. Based on this idea, the self-service examination mode breaks traditional thinking about examination, where the teachers design the test and students answer the questions. Self-service assessment mode transforms teaching objectives into several test modules in accordance with teaching focal points and difficult points. Taking the course of "Human Resource Professional English" as an example, this paper explained self-service assessment method.

\section{What is Self-Service Examination Mode}

Human Resource Professional English is the faculty's compulsory course that must be taken by the students in school of HRM. The objective of this course is to enhance specialized English vocabulary, English reading, listening and speaking ability and strengthen social adaptation ability of HRM majored students. According to the teaching program of Human Resource Professional English, there are six basic teaching tasks from both theoretical and practical perspectives(table.1). These teaching tasks are called "expected learning outcomes". Realization of expected learning outcomes is conducted through teachers' explanation and classroom activities. In self-service examination, "expected learning outcomes" should be transformed into examination modules and teachers set test options on the basis of these modules. (table 2)

After first half of a term, students can submit their exam menus(table 3) and the teacher will arrange the time for their examinations. The deadline of menu submitting is the last week of the term.

In the examination menu, each item is worth 100 points. Selection of exam items is of no limitation. The more items a student chooses, the higher his or her score will be.

Total score is the sum of scores of all selected items, but each weighted by a certain coefficient.

The total score that a student selected can be more than, less than or equal to 100 points. If the points are less than 100 , or equal to 100 , the final score is recorded as the actual points he or she acquired in the examination. However, if he or she selects items are more than 100 points , the final results need to be converted in accordance with the formula as follow.

$\mathrm{X}=100 \mathrm{~S} / \mathrm{C}$ 
Where $\mathrm{X}$ stands for the final score, $\mathrm{C}$ refers to the cumulative score of selected items and $\mathrm{S}$ means the actual score that a student got

Example: a student selects 140 marks and wins 124, so his final score is:

$\mathrm{X}=100 * 124 / 140=89$ (marks)

Table 1. Human resource professional English teaching programmed.

\begin{tabular}{c|c|c}
\hline $\begin{array}{c}\text { Teaching } \\
\text { objects }\end{array}$ & Tasks & Techniques \\
\hline \multirow{4}{*}{ Theory } & 1.HRM Vocabulary & Oral work and practice \\
\cline { 2 - 3 } & $\begin{array}{c}\text { 2.HRM theories, models, roles and practices } \\
\text { in the HRM (English reading) }\end{array}$ & Situational dialogue \\
\hline \multirow{4}{*}{ Application } & $\begin{array}{c}\text { 1.To develop students' speaking and listening } \\
\text { skills }\end{array}$ & Textbook reading \\
\cline { 2 - 3 } & $\begin{array}{c}\text { 2. To develop an understanding of theory and } \\
\text { practice of HRM }\end{array}$ & $\begin{array}{c}\text { Textbook reading and } \\
\text { translation }\end{array}$ \\
\cline { 2 - 3 } & $\begin{array}{c}\text { 3.Be able to relate HRM theory to the reality of } \\
\text { HR and work practices }\end{array}$ & $\begin{array}{c}\text { Oral English practice and } \\
\text { scenario simulation }\end{array}$ \\
\hline
\end{tabular}

Table 2. Teaching outcomes and exam modules

\begin{tabular}{|c|c|c|c|c|}
\hline Learning outcomes & $\begin{array}{c}\text { Exam } \\
\text { modules }\end{array}$ & Exam options & Score & Weight \\
\hline $\begin{array}{l}\text { To develop students' speaking and } \\
\text { listening skills }\end{array}$ & \multirow{2}{*}{ Listening } & Dictation & 100 & $20 \%$ \\
\hline $\begin{array}{l}\text { By watching movies and imitating movie } \\
\text { characters, oral fluency will be increased }\end{array}$ & & Movie Dubbing & 100 & $20 \%$ \\
\hline $\begin{array}{c}\text { Be able to relate HRM theory to the reality } \\
\text { of HR and work practices }\end{array}$ & \multirow{3}{*}{ Speaking } & $\begin{array}{l}\text { A free talk between } \\
\text { two students }\end{array}$ & 100 & $20 \%$ \\
\hline Be able to communicate effectively & & Group discussion & 100 & $10 \%$ \\
\hline $\begin{array}{l}\text { Convey ideas and opinions using college } \\
\text { level spoken English }\end{array}$ & & Ask and answer & 100 & $10 \%$ \\
\hline $\begin{array}{c}\text { To develop an understanding of theory and } \\
\text { practice of HRM }\end{array}$ & \multirow{2}{*}{ Reading } & Read the text & 100 & $20 \%$ \\
\hline To improve reading ability & & $\begin{array}{l}\text { Reading } \\
\text { comprehension }\end{array}$ & 100 & $20 \%$ \\
\hline $\begin{array}{c}\text { Master more than } 500 \text { professional words } \\
\text { of HRM }\end{array}$ & \multirow{2}{*}{ Writing } & Words reciting & 100 & $20 \%$ \\
\hline $\begin{array}{l}\text { Critically thinking and analyse issues of } \\
\text { HRM }\end{array}$ & & $\begin{array}{l}\text { Answer the questions } \\
\text { in English }\end{array}$ & 100 & $20 \%$ \\
\hline Total & & & & $100 \%$ \\
\hline
\end{tabular}


Table 3. Human resource professional English examination MENU

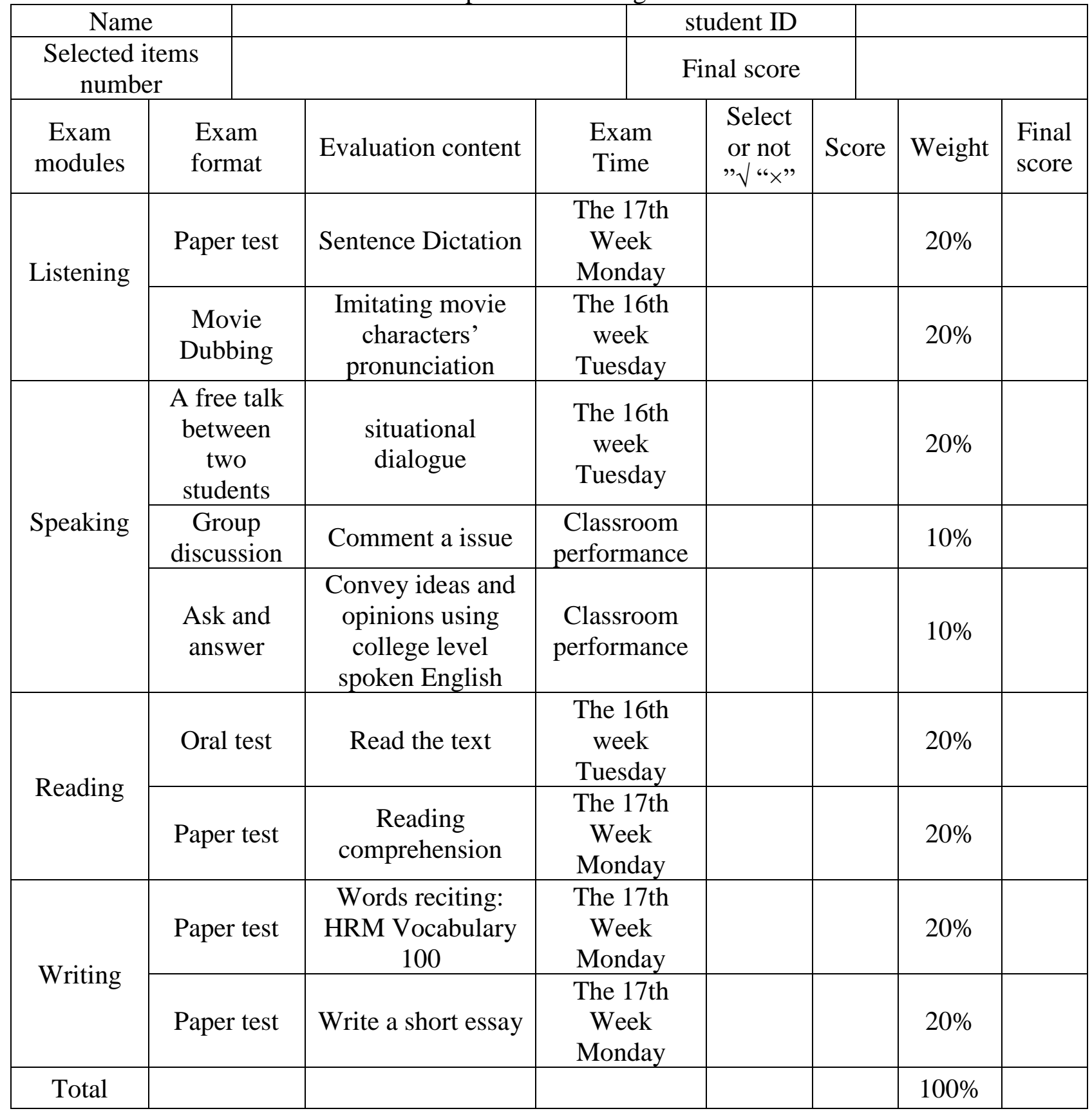

\section{What Is Novelty About Self-Service Assessment Mode}

Score setting of self-service examination is different from traditional ones. Normally, the total score of the traditional exams worth 100 points. In self-service assessment, total score can be more than 100 points. A student can select his exam menu that worth less than, more than or equal to 100 points. The more items they choose, less points of making mistakes they will have. For example: a student chooses a menu worth 100 marks. If he makes a mistake in a problem worth 20,20 will be subtracted from his score. Another student chooses a menu worth 140 marks. If he makes a mistake in a problem worth $20, X=100 * 20 / 140=14$ (marks) will be subtracted. The aim of self-service exam is to encourage good students and motivate weak students. 


\section{Conclusion}

\subsection{Advantages of Self-Service Assessment:}

(1) Students can evaluate their learning situation through menu selection. For students who have strong learning ability can choose more items to win higher score. Weak students can find out their weaknesses to conduct self-study.

(2) self-service assessment breaks traditional examination thinking and makes exams more flexible. Through self-service assessment, students will hold a more active and serious attitude to classroom learning.

(3) This new assessment idea requires teachers to have more profound understanding of teaching program, diversity of teaching methods is required as well.

\subsection{Shortcoming of Self-Service Assessment}

(1) Workload of teachers increases.

(2) Compared with traditional exams, the self-service exam mode needs more time.

\section{References}

[1]. Jun Liu, Tianshu Li, on course examination way of Mechanical Innovation Design based on fuzzy comprehensive evaluation, Journal of Southwest China Normal University (Natural Science Edition). vol.40 (2015), 177-180

[2]. Vishwakarma Kirti, Sharma Mukesh, Matreja Prithpal Singh, et al. Introducing objectives structured practical examination as a method of learning and evaluation for undergraduate pharmacology, Indian journal of pharmacology, 2016, 47-51

[3]. Azrul A. Mutalib, Roszilah Hamid, Firdaus Mohd. Hamzah, et al. Implementation of OBE in the Engineering Graphics Course and Analysis Academic Performance, Procedia-Social and Behavioral Sciences, 2012,184-188

[4]. lbert Chan, Chi-Hung Chan, A new outcome-based curriculum: its impact on student core competence, Journal of Applied Research in Higher Education, 2009, 24-32

[5]. Jingjign Ji: The Construction of University Curriculum Examination Quality Management System based on the Theory of TQM, Master Degree, Jiangsu Normal University, China, 2017. 